Gut, 1975, 16, 759-765

\title{
Stimulation of water and sodium secretion and inhibition of glucose absorption from the rat jejunum during intraarterial infusions of prostaglandins
}

\author{
I. M. COUPAR ${ }^{1}$ AND IAN MCCOLL \\ From the Department of Surgery, Guy's Hospital, London
}

SUMMARY The effect of prostaglandins, isoprenaline and dibutyryl cyclic adenosine monophosphate (dibut cAMP) on the net transfer of water and $\mathrm{Na}^{+}$and glucose absorption have been studied in the anaesthetized rat.

The lumen of the jejunum was recirculated with a solution of normal saline containing $D(+)$ glucose and phenosulphonphthalein. The superior mesenteric artery was perfused extracorporeally and drugs were infused into the arterial blood.

Prostaglandin $\mathrm{E}_{1}\left(\mathrm{PGE}_{1}\right)$ at infusion rates of $2.5 \times 10^{-9}$ and $10^{-8} \mathrm{~mol} / \mathrm{min}$ induced a net secretion of water and $\mathrm{Na}^{+}$which was significantly different from the infused control mean. Both water and $\mathrm{Na}^{+}$secretion were dose-related. $\mathrm{PGE}_{1}$ induced slight but significant inhibition of glucose absorption at $10^{-8} \mathrm{~mol} / \mathrm{min}$. This could either be a direct effect or secondary to solvent drag.

$\mathrm{PGE}_{2}\left(2.5 \times 10^{-9} \mathrm{~mol} / \mathrm{min}\right)$ and $\mathrm{PGF}_{2 \alpha}\left(8 \times 10^{-9} \mathrm{~mol} / \mathrm{min}\right)$ induced water and $\mathrm{Na}^{+}$secretion, and inhibited glucose absorption but not significantly.

Isoprenaline $\left(10^{-9} \mathrm{~mol} / \mathrm{min}\right)$ and dibut $\mathrm{cAMP}\left(8 \times 10^{-9} \mathrm{~mol} / \mathrm{min}\right)$ did not alter water, $\mathrm{Na}^{+}$or glucose absorption.

Prostaglandins affect gastrointestinal motility by a direct action on smooth muscle, alter intestinal blood flow (Waller, 1973; Nakano, 1973) and promote the secretion of fluid and electrolytes into the lumen (Greenough, Pierce, Al-Awqati, and Carpenter, 1969; Matuchansky and Bernier, 1971). They are present within the gut wall of animals and man (Waller, 1973) and are released by vagal stimulation in the rat small intestine (Radmanovic, 1968). The effect of prostaglandin-induced secretion is similar to that produced by cholera exterotoxin (CE) and both may act on a common secretory process (Pierce, Carpenter, Elliot, and Greenough, 1971). Glucose has been shown to stimulate the mucosal to-serosal flux of water, $\mathrm{Na}^{+}$and $\mathrm{Cl}^{-}$during prostaglandin and CE-induced secretion (Al-Awqati, Cameron, Field, and Greenough, 1970a; Al-Awqati and Greenough, 1972) but there is little available information on the effect of prostaglandins on the active absorption of glucose itself. Preliminary

1Present address: Department of Physiology, Monash University, Clayton 3186, Australia.

Received for publication 9 July 1975. investigations indicated that recirculation of prostaglandin $\mathrm{E}_{1}\left(\mathrm{PGE}_{1}\right), \mathrm{E}_{2}$ and $\mathrm{F}_{2_{\alpha}}$ through the lumen of the rat jejunum in vivo caused a small inhibition of glucose absorption (Coupar and McColl, 1972). However, PGE $_{1}$ is mostly oxidized in the lumen of the rat jejunum and only a small amount is absorbed (Parkinson and Schneider, 1969). The purpose of the following experiments was to study the effect of $P_{1} E_{1}, E_{2}$ and $F_{2_{\alpha}}$ when present in the blood on glucose absorption from the lumen of the rat jejunum. Isoprenaline and dibut cAMP were also used as a preliminary investigation into the action of prostaglandins on glucose absorption. Isoprenaline was used to determine whether intestinal transport was altered indirectly as a result of vasodilatation as it is a potent vasodilator but does not affect the mucosa directly. The secretory response of the small intestine induced with prostaglandins is associated with increased intracellular levels of 3,5 cyclic adenosine monophosphate (3,5 cAMP). The more potent derivative, dibut cAMP, was used in an attempt to mimic secretion of water and $\mathrm{Na}^{+}$and investigate whether this was associated with the inhibition of glucose absorption. 


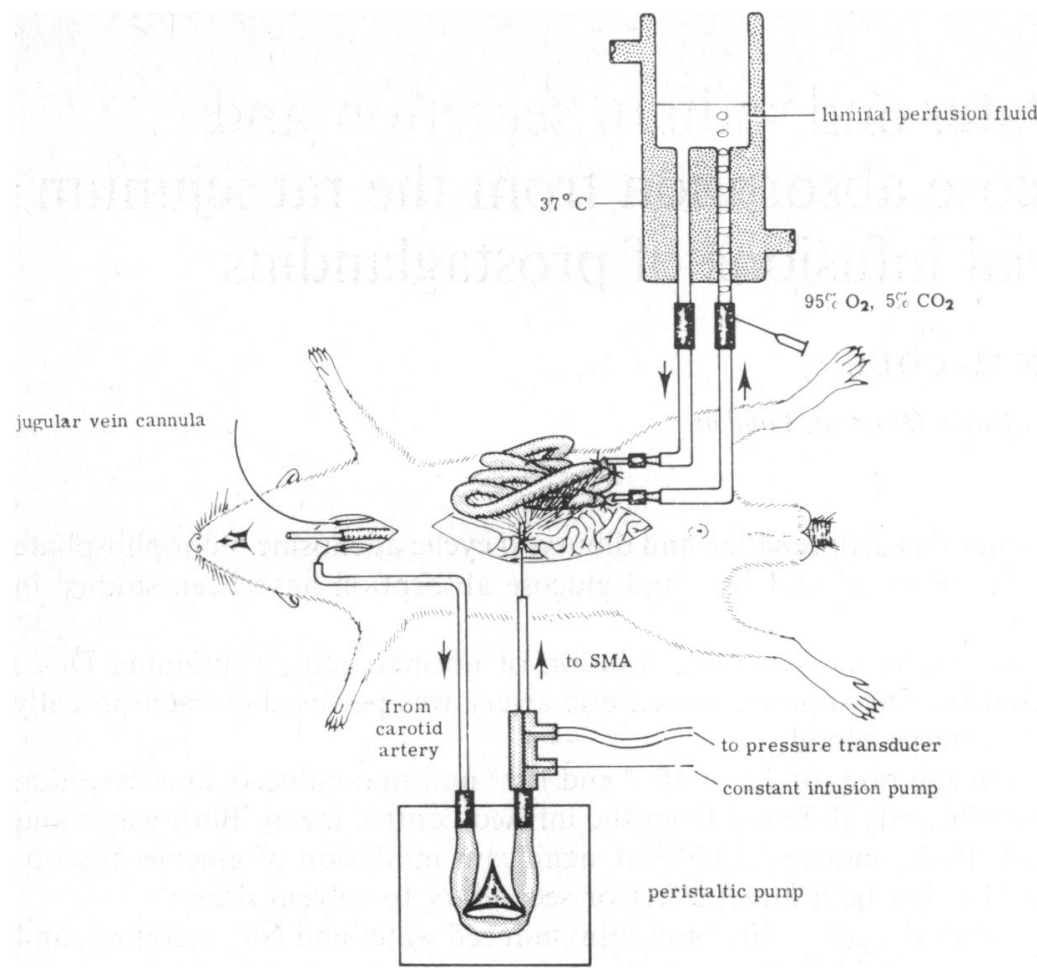

Fig 1 Diagram showing the method for perfusing the lumen of the jejunum during vascular perfusion

\section{Methods}

\section{APPARATUS}

The apparatus consisted of two independent circuits, one for perfusing the superior mesenteric artery (SMA) with blood and the other for perfusing the lumen of the proximal small intestine with fluid (fig 1).

\section{SMA PERFUSION}

Blood was diverted from the right common carotid artery into the SMA by a peristaltic pump (Schuco Scientific Ltd). The pump tube (2.5 mm ID) inflow (from carotid artery) and outflow (to SMA) tubes (1 mm ID) were of silicone rubber. The circuit consisted of two plastic connecting pieces, a glass piece with double side arms and polythene arterial cannulae which were siliconized (Repelcote, Hopkins and Williams Ltd). The glass piece was used for infusing drugs and as a point to record pressure. During perfusion the arms were kept upright to act also as bubble traps. The arterial cannulae were short lengths $(2 \mathrm{~cm})$ of polythene tubing (Portex Ltd). The carotid artery cannula $(0.4 \times 0.8 \mathrm{~mm})$ was sealed into the silicone rubber tube attached to the inflow of the pump with silicone rubber compound.
The SMA cannula $(0.5 \times 1.0 \mathrm{~mm})$ was sealed into the silicone rubber tube connected to the outflow. The flow from the pump was pulsatile (180 pulses/ min, pulse pressure approximately $20 \mathrm{mmHg}$ ) and was approximately $10 \mathrm{ml} / \mathrm{min}$ (range $9-11 \mathrm{ml} / \mathrm{min}$ ). The pump and tubes were primed before each experiment with normal saline containing $10 \%$ dextran 40 (Pharmacia AB). The volume of this solution was $0.8 \mathrm{ml}$.

A recirculation technique was used for perfusing the intestine. The composition of the luminal perfusing fluid was 154 m-equiv/l $\mathrm{Na}^{+}, 154 \mathrm{~m}$ equiv/ $1 \mathrm{Cl}^{-}, 5.55 \mathrm{mM}(100 \mathrm{mg} \%) \mathrm{d}(+)$ glucose, $5.6 \mathrm{mM}(2 \mathrm{mg} \%)$ phenolsulphonphthalein (PSP) in distilled water. The solution was initially at pH 5.3 and was continuously recirculated through the loop from a glass reservoir (maintained at $37^{\circ} \mathrm{C}$ ) by bubbling a mixture of $95 \%$ oxygen, and $5 \%$ carbon dioxide into the reservoir inlet as previously described by Nissim (1965) (fig 1). The height of the fluid in the reservoir was approximately $10 \mathrm{~cm}$ above the midpoint of the loop.

\section{OPERATIVE PROCEDURES}

Male Wistar rats, $400 \mathrm{~g}$, fasted overnight, were anaesthetized by a subcutaneous injection of $8 \mathrm{mg}$ / 
$100 \mathrm{~g}$ body weight pentobarbitone sodium. The rats were placed on an electrically heated pad (approximately $35^{\circ} \mathrm{C}$ ), the trachea was cannulated and a piece of saline-filled polythene tubing $(0.4 \times$ $0.8 \mathrm{~mm}$ ) was tied into the jugular vein. A mid-line incision was made in the abdomen and a glass cannula was tied proximally into the small intestine at the ligament of Treitz and a second glass cannula was tied into the lumen approximately $50 \mathrm{~cm}$ distally. The SMA was carefully cleared for later cannulation. The animal was given $250 \mathrm{U}$ of heparin through the jugular vein cannula and the right common carotid artery was cannulated. The loop of jejunum was connected via its cannulae to the glass reservoir and perfusion of the lumen was started. The loop received no blood for approximately two min while the SMA was cannulated. The peristaltic pump was switched on (time 0 ) and the luminal perfusion was stopped. At five min either normal saline (SMA control) or drug (treatment) was infused throughout the experiment from a constant infusion pump (Harvard Apparatus Co, Inc, model 975) via a length of polythene tube $(0.5 \times 1.0 \mathrm{~mm})$ into one side-arm of the glass piece. The infusion rate was $0.0188 \mathrm{ml} / \mathrm{min}$ in all experiments. Perfusion pressure in the superior mesenteric artery was measured from the second side arm by a pressure transducer connected to a pen recorder (Devices Ltd, model M.4). The loop was gently squeezed along its length to remove fluid, was connected again via its cannulae to the glass reservoir and $20 \mathrm{ml}$ of luminal perfusing fluid was recirculated $15 \mathrm{~min}$ after starting SMA perfusion. The luminal perfusion was stopped after $20 \mathrm{~min}(35 \mathrm{~min}$ SMA perfusion) and a sample of blood was collected into a tube containing sufficient $\mathrm{NaF}$ to prevent glycolysis. The animal was killed by bleeding. Throughout the operative procedure care was taken to keep the intestine moist with warm saline and to avoid damaging the mesentery. The intestine and loop were placed in the abdominal cavity during the 20-min luminal perfusion and during stages of the operative procedure when the loop and SMA were not being prepared. At the end of the experiment the loop was removed from the animal, was squeezed along its length to remove fluid and mucus, was blotted with tissue paper and was weighed. The fluid from the reservoir and lumen was collected for analysis.

\section{PRESENTATION OF RESULTS}

The luminal perfusing fluid contained PSP as a non-absorbable marker and changes in its concentration were used to calculate net water transfer.

Net water transfer is expressed as the amount absorbed $(+)$ or secreted $(-)$ by unit weight of intestine during the 20-min perfusion $(\mathrm{mmol} / \mathrm{g}$ in $20 \mathrm{~min}$ ). Glucose absorption and net $\mathrm{Na}^{+}$ transfer were calculated from the difference in original and final amounts in the luminal perfusing fluid and expressed as $\mu \mathrm{mol} / \mathrm{g}$ and $\mu$-equiv $/ \mathrm{g}$ in 20 min respectively.

\section{STATISTICAL ANALYSIS}

Control and drug treatments were randomized. The relationship between loop weight and net absorption of glucose, water and $\mathrm{Na}^{+}$(as expressed above) in the SMA control group was analysed by calculating the correlation coefficient ( $r$ ). Where no correlation was shown (water and $\mathrm{Na}^{+}$results) one-way analysis of variance was used to demonstrate if the treatment means differed significantly. The means of glucose absorption were corrected for the negative correlation of intestinal weight on glucose absorption and were also tested for significant differences by analysis of covariance (Cochran and Cox, 1957). Individual treatment means were compared to the SMA control mean by the product of the residual standard error ('effective residual standard error' in the glucose results) and the Studentized range, $Q$. The $Q$ method has the property that if some or all of the differences between pairs are tested, the probability that no erroneous claim of significance is made is $>0.95$ (Snedecor and Cochran, 1967).

\section{DRUGS}

The samples of prostaglandins $\mathrm{E}_{1}, \mathrm{E}_{2}$ and $\mathrm{F}_{2_{\alpha^{-}}}$ tromethamine were generously given by $\mathrm{Dr}$ J. E. Pike of the Upjohn Co, Kalamazoo, Michigan, USA; monosodium $\mathrm{N}^{6}$-2'-O-dibutyryl-adenosine3'-5' monophosphate (dibut cAMP) by the Boehringer Corporation, and isoprenaline sulphate, BP, by McCarthys Ltd. The stock solutions of drugs were diluted with normal saline before use to give the required concentration for infusion into the superior mesenteric artery. Heparin was available as heparin injection BP (mucous) and pentobarbitone as pentobarbitone sodium, B.Vet.C.

\section{ANALYSIS}

Blood glucose and glucose in the luminal fluid were estimated colorimetrically using the glucose oxidase/ peroxidase method (Boehringer Corporation Ltd) on an AutoAnalyzer (Technicon Instrument Co Ltd); PSP was also estimated colorimetrically (directly at $560 \mathrm{~nm}$ ). The $\mathrm{Na}^{+}$concentration was estimated by a flame photometer (Evans Electroselenium Ltd).

\section{HISTOLOGY}

A specimen from the middle of each loop (jejunum) was taken and fixed in $10 \%$ normal saline for 24 
hours. After clearing and mounting wax sections were stained with haematoxylin and eosin.

\section{Results}

\section{MORPHOLOGY}

There was no evidence under the light microscope of vascular congestion, aggregates of red cells or increased numbers of inflammatory cells in any of the specimens. Some cellular material was seen in the lumen of approximately $25 \%$ of specimens, including controls, and was probably sloughed epithelium from villous tips but the villi appeared normal in all specimens.

\section{SUPERIOR MESENTERIC ARTERY PERFUSION PRESSURE}

The resting SMA perfusion pressure (mean and standard error) measured immediately before infusions at five minutes was $112 \pm 5 \mathrm{~mm} \mathrm{Hg}(1 \mathrm{mmHg}$ $=1.333$ mbar $)(n=50)$. In the SMA control group $(\mathrm{n}=10)$ perfusion pressure was $114 \pm 6 \mathrm{mmHg}$ at five $\mathrm{min}$ and increased to $129 \pm 7$ at $15 \mathrm{~min}$ and $128 \pm 11 \mathrm{mmHg}$ at 35 minutes. The pressure was similar to the SMA control group when $\mathrm{PGE}_{2}$ $\left(2.5 \times 10^{-9} \mathrm{~mol} / \mathrm{min}\right), \mathrm{PGF}_{2 \alpha}\left(8 \times 10^{-9} \mathrm{~mol} / \mathrm{min}\right)$ and dibut cAMP $\left(8 \times 10^{-9} \mathrm{~mol} / \mathrm{min}\right)$ were infused but was lower than the SMA control group at 15 and $35 \mathrm{~min}$ when $\mathrm{PGE}_{1}\left(6.25 \times 10^{-10}, 2.5 \times\right.$ $10^{-9}$ and $\left.10^{-8} \mathrm{~mol} / \mathrm{min}\right)$ and isoprenaline $\left(10^{-9}\right.$ $\mathrm{mol} / \mathrm{min}$ ) were infused (table I). Estimates of the minimum molar blood concentration resulting from these infusions are shown also in table I and are based on assuming complete clearance from the blood after one circulation.

\section{WATER AND NA ${ }^{+}$TRANSPORT AND \\ GLUCOSE ABSORPTION}

The blood glucose concentration at the end of the experiments (SMA perfusion for 35 minutes) was $4.02 \pm 0.2 \mathrm{mM}$ and treatment means were not significantly different $(F=0.06, P>0.05)$. The length of the loops was $51 \mathrm{~cm}$ (range 42-60) and weighed $3.696 \mathrm{~g}$ (range 3 to 4.4 ). There was a negative correlation between loop weight and glucose absorbed/g in $20 \mathrm{~min}$ in the SMA controls $(r=-0.88, n=10)$ but not between weight and net

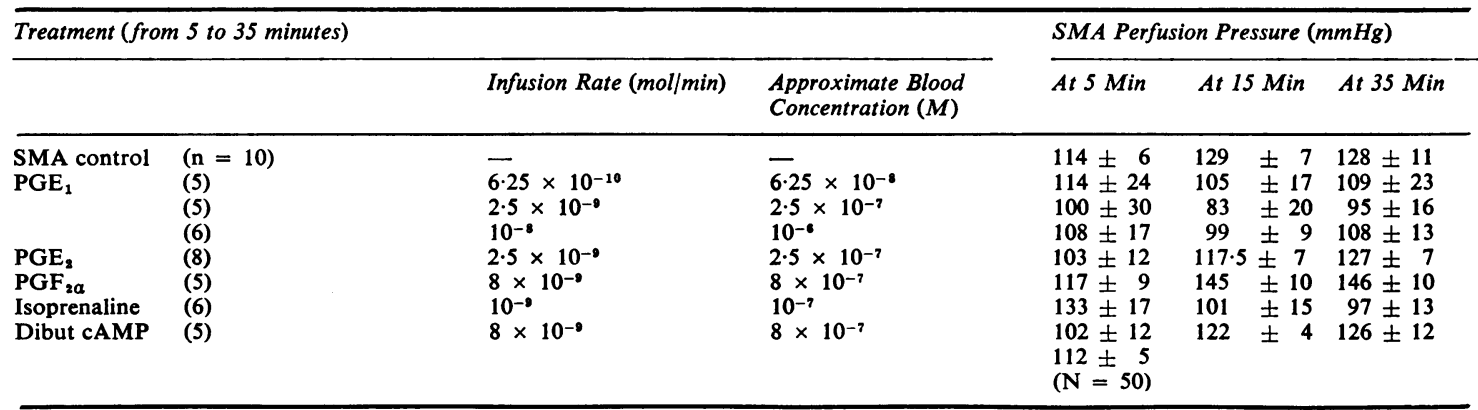

Table I Superior mesenteric artery perfusion pressure during infusion of saline (SMA control), prostaglandins, isoprenaline and dibut cAMP ${ }^{1}$

${ }^{1}$ Approximate blood concentrations given above are minimum estimates assuming that the drugs are completely cleared from the blood by one circulation.

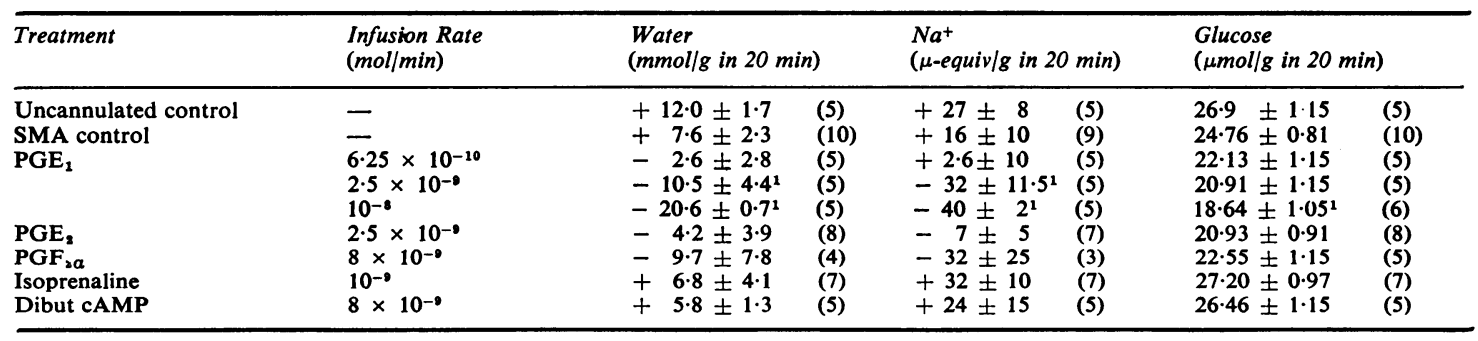

Table II Net transfer (absorption +, secretion -) of water and $\mathrm{Na}^{+}$and absorption of glucose during $\mathrm{SMA}$ perfusion with prostaglandins, isoprenaline and dibut cAMP

1 = significantly different from the SMA control mean $(P<0.05)$. For glucose absorption the following pairs were also significantly different; isoprenaline and $\mathrm{PGE}_{1}\left(2.5 \times 10^{-9} \mathrm{~mol} / \mathrm{min}\right)$, isoprenaline and $\mathrm{PGE}_{1}\left(10^{-8} \mathrm{~mol} / \mathrm{min}\right)$, isoprenaline and $\mathrm{PGE}$, dibut $\mathrm{cAMP}$ and $\mathrm{PGE},(2.5 \times$ $\left.10^{-9} \mathrm{~mol} / \mathrm{min}\right)$, dibut $\mathrm{cAMP}$ and $\mathrm{PGE}_{1}\left(10^{-8} \mathrm{~mol} / \mathrm{min}\right)$, dibut $\mathrm{cAMP}$ and $\mathrm{PGE}_{2}(\mathrm{P}<0.05)$. There were no significant differences between the uncannulated and SMA control groups with respect to water, glucose and $\mathrm{Na}^{+}$absorption. 
water $(r=-0.23)$ or net $\mathrm{Na}^{+}(\mathrm{r}=0)$ absorbed $/ \mathrm{g}$ in 20 minutes.

The values for water and $\mathrm{Na}^{+}$transport and glucose absorption in control and drug treatments are shown in table II. Treatment means were significantly different for water transport $(\mathrm{F}=8.7, \mathrm{P}<$ $0.005), \mathrm{Na}^{+}$transport $(\mathrm{F}=6.59, \mathrm{P}<0.005)$ and glucose absorption $(\mathrm{F}=12.11, \mathrm{P}<0.005)$.

$\mathrm{PGE}_{1}$ at infusion rates of $2.5 \times 10^{-9}$ and $10^{-8}$ $\mathrm{mol} / \mathrm{min}$ induced a net secretion of water and $\mathrm{Na}^{+}$ which was significantly different from the salineinfused control mean. A slight but significant inhibition of glucose absorption occurred at $10^{-8}$ $\mathrm{mol} /$ minute. These effects of $\mathrm{PGE}_{1}$ on water and $\mathrm{Na}^{+}$secretion and glucose absorption were doserelated. There was a positive correlation $(r=0.77)$ between inhibition of glucose absorption and net water secretion in the individual results of SMA controls and those infused with $\mathrm{PGE}_{1}$ (fig 2).

PGE $_{2}\left(2.5 \times 10^{-9} \mathrm{~mol} / \mathrm{min}\right)$ and $\mathrm{PGF}_{2_{\alpha}}(8 \times$ $10^{-9} \mathrm{~mol} / \mathrm{min}$ ) induced water and $\mathrm{Na}^{+}$secretion and inhibited glucose absorption but not significantly.

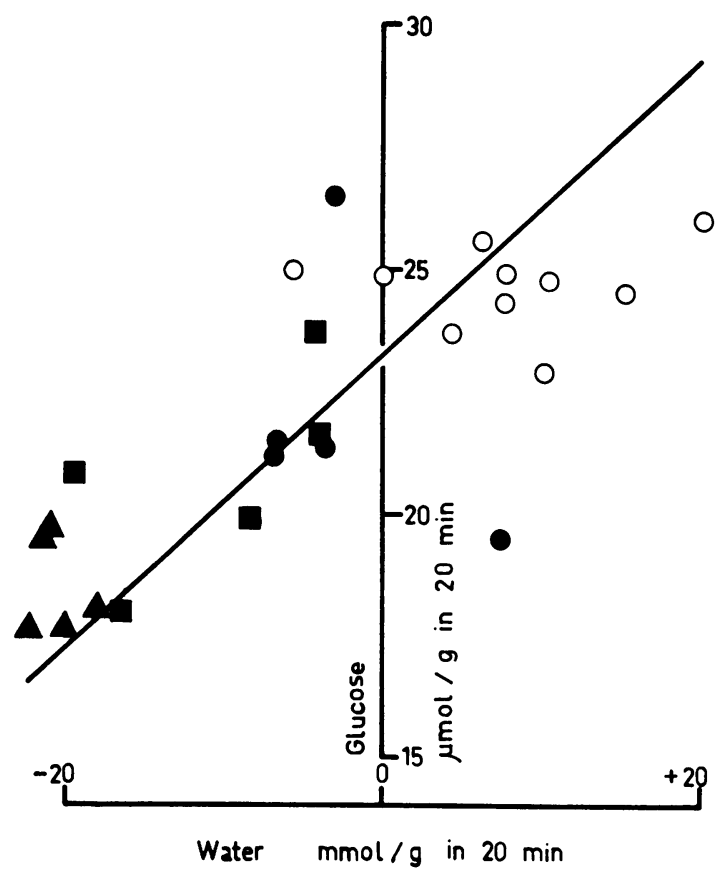

Fig 2 Correlation between glucose absorption (corrected for regression of glucose absorption on intestinal weight) and water transport $(+=$ net absorption, $-=$ net secretion) from individual treatments. SMA controls, $6.25 \times 10^{-10}, \square 2.5 \times 10^{-9}$ and $\triangle 10^{-8} \mathrm{~mol} \mathrm{PGE} /$ minute. Regression coefficient $=$ $3 \cdot 36, r=+0 \cdot 767$, intercept at zero glucose absorption $=-78.13 \mathrm{mmol}$ water $/ \mathrm{g}$ in 20 minutes.
Isoprenaline $\left(10^{-9} \mathrm{~mol} / \mathrm{min}\right)$ and dibut cAMP $(8 \times$ $10^{-9} \mathrm{~mol} / \mathrm{min}$ ) did not alter water, $\mathrm{Na}^{+}$or glucose absorption.

\section{Discussion}

Although prostaglandins are relatively stable in whole blood (Ferreira and Vane, 1967), most are almost completely removed from the blood by a single circulation. As much as 85 to $90 \%$ of $\mathrm{PGE}_{1}$ is inactivated by a single pass through the rat liver (Dawson, Jessup, McDonald-Gibson, Ramwell, and Shaw, 1970) and $P_{G E}, E_{2}$ and $F_{2 \alpha}$ are also inactivated in the lungs of the guinea pig, cat and dog (Piper, Vane, and Wyllie, 1970; Ferreira and Vane, 1967). Isoprenaline is also inactivated relatively rapidly by catechol O-methyltransferase in the rat (Hertting, 1964) so it was necessary to devise a technique of infusing these compounds directly into the arterial blood supply of the intestine.

During the relatively short vascular perfusion of the SMA reported here $(35 \mathrm{~min})$ the jejunum absorbed a similar amount of glucose as the uncannulated control group. Active absorption occurred in all treatments as the glucose concentration in the lumen at the end of the perfusion was always lower than the blood glucose concentration. The SMA control group also absorbed a similar net amount of water and $\mathrm{Na}^{+}$as the uncannulated control group and the normality of the loops after perfusion was confirmed by histological examination.

The SMA was perfused at $10 \mathrm{ml} / \mathrm{min}$ since the flow rate in vivo in ether-anaesthetized rats is 8$10 \mathrm{ml} / \mathrm{min}$ at $95 \mathrm{mmHg}$ (Windmueller, Spaeth, and Ganote, 1970). Perfusion pressure was $112 \pm 5$ $\mathrm{mmHg}$ after five min but gradually increased in the SMA control group. The lower perfusion pressures during infusions of $\mathrm{PGE}_{1}$ support previous findings that $\mathrm{PGE}_{1}$ decreases peripheral resistance (Weeks and Wingerson, 1964) by increasing the diameter of arterioles, metarterioles, precapillary sphincters and muscular venules in the rat intestine (Viguera and Sunahara, 1969; Weiner and Kaley, 1969). The low perfusion pressure during isoprenaline infusion compared with the SMA control group is also in agreement with the drug's action as a potent vasodilator (Innes and Nickerson, 1970). Perfusion pressure was similar to the SMA control group during infusions of $\mathrm{PGE}_{2}$ and dibut cAMP. There appears to be no information in the literature about the vascular effects of these compounds in the rat and the present results would suggest that they do not affect intestinal peripheral resistance at the infusion rates used. PGF $_{2 \alpha}$ decreases blood flow in the rat intestine by constricting arterioles (Viguera 
and Sunahara, 1969) but the results reported here do not confirm this observation.

The large net secretion of water and $\mathrm{Na}^{+}$into the lumen during infusions of $\mathrm{PGE}_{1}$ confirms in the rat this previously known effect in the dog (Greenough et al, 1969), rabbit (Al-Awqati, Field, Pierce, and Greenough, 1970b) and man (Matuchansky and Bernier, 1971). PGE 1 caused a dose-related inhibition of glucose absorption and at the highest infusion rate was significantly different from the SMA control group. This infusion rate $\left(10^{-8} \mathrm{~mol} / \mathrm{min}\right)$ gave an approximate minimum blood concentration of $10^{-6} \mathrm{M}$ and confirms previous studies in the anaesthetized rat where intraluminal $P G_{1}$ also inhibited glucose absorption. However, a higher initial concentration of $1.4 \times 10^{-4} \mathrm{M}$ was necessary to produce significant inhibition of glucose absorption (Coupar and McColl, 1972). PGE $_{1}$ is also more potent in producing fluid and electrolyte secretion in the dog jejunum when infused intraarterially than intraluminally (Pierce et al, 1971). This difference in potency of PGE $_{1}$ on serosal and mucosal surfaces may be due to a faster inactivation at the luminal surface than at the serosal surface. It has been shown that $\mathrm{PGE}_{1}$ is rapidly oxidized in the lumen of the rat isolated jejunum (Parkinson and Schneider, 1969).

As $\mathrm{PGE}_{1}$ increases blood glucose levels in several species including the rat (Nakano, 1973), and as glucose absorption is enhanced in isolated intestines from hyperglycaemic rats (Casey, Felber, and Vannotti, 1968), we might expect $\mathrm{PGE}_{1}$ to increase glucose absorption. However, none of the infusions significantly altered blood glucose concentration. Glucose absorption can also be influenced by changes in blood flow in the intestine. The rate of 3-O-methylglucose absorption from the rat jejunum increases with increasing blood flow (Lichtenstein and Winne, 1973). Although the experiments reported here were at constant flow the prostaglandins may still affect absorption by changing the distribution of blood within the microcirculation of the intestine. Isoprenaline was infused since it is a potent vasodilator, but does not affect unidirectional fluxes of $\mathrm{Na}^{+}$and $\mathrm{Cl}^{-}$in the rabbit isolated ileal mucosa (Field and McColl, 1968; McColl, Field, and Silen, 1968). However it did not alter glucose absorption at an infusion rate which lowered SMA perfusion pressure to a similar value as infusions of $\mathrm{PGE}_{1}$. This suggests that the effect of $\mathrm{PGE}_{1}$ on glucose absorption does not occur as an indirect result of vasodilatation.

The effects of prostaglandins and cholera enterotoxin on ion flux are both strikingly similar to those induced by 3,5 cAMP (Field and McColl, 1968; Field, Plotkin, and Silen, 1968; Field, Fromm, and
Silen, 1969; Al-Awqati et al, 1970a and b; Al-Awqati and Greenough, 1972). Moreover, PGE 1 , $E_{2}$ and cholera enterotoxin are potent inducers of 3,5 cAMP formation in the small intestinal mucosa of the guinea-pig, rabbit and rat (Kimberg, Field, Johnson, Henderson, and Gershon, 1971; Sharp and Hynie, 1971). However, there appears to be one distinction between their effects since cholera enterotoxin does not alter glucose absorption from the dog and rabbit small intestine (Iber, McGonagle, Serebro, Luebbers, Bayless, and Hendrix, 1969; Serebro, Bayless, Hendrix, Iber, and McGonagle, 1968). Further studies will be of interest in confirming whether this difference is real or due only to differences in species or methods used. If prostaglandin-induced inhibition of glucose absorption is mediated by increased intracellular levels of 3,5 cAMP it might be expected that infusion of dibut cAMP would also inhibit glucose absorption as well as mimic water and $\mathrm{Na}^{+}$secretion. This was expected as it has been shown that 3,5 cAMP itself $\left(10^{-6} \mathrm{M}\right.$ on the serosal surface) inhibits glucose absorption in the rat isolated intestine (Casey and Harrington, 1971). However, this effect is not confirmed by the in-vivo results reported here since infusion of dibut cAMP giving an approximate blood concentration of $8 \times 10^{-7} \mathrm{M}$ did not significantly alter glucose absorption or water and $\mathrm{Na}^{+}$transport. The reason why a similar concentration of dibut cAMP as cAMP was without effect on glucose absorption is not clear. Although the dibutyryl derivative of cAMP is generally more potent than cAMP one possiblity is that cAMP may accumulate more rapidly in the mucosa in vitro due to the absence of blood flow.

It must be emphasized that the effect of the prostaglandins on glucose absorption is small and occurs in the presence of a large net secretion of water and $\mathrm{Na}^{+}$. Such results may be explained by 'solvent drag' (the resistance to solute flow produced by a large flow of solvent in the opposite direction). Inhibition of glucose absorption is positively correlated with decrease in net water absorption (increased secretion) (fig 2). Taking the differences in mean values between SMA controls and those infused with $\mathrm{PGE}_{1}\left(10^{-8}\right.$ $\mathrm{mol} / \mathrm{min}$ ) from table II, an estimated inhibition of $6 \mu \mathrm{mol}$ of glucose occurs during a net change in flux of water from absorption to secretion of 28 $\mathrm{mmol} / \mathrm{g}$ in 20 minutes. Other studies have indicated that glucose absorption may be inhibited by solvent drag. Glucose absorption is significantly depressed from the hamster isolated jejunum if water absorption is decreased by making the mucosal fluid hypertonic (Dinda, Beck, and Beck, 1972). Recent studies in human subjects have confirmed that $\mathrm{PGE}_{1}$ (approximately $6 \mu \mathrm{g} / \mathrm{ml}-1.7 \times 10^{-5} \mathrm{M}$ ) delivered 
intrajejunally causes a large reversal of water flux from absorption to secretion associated with a small inhibition (25\%) of glucose absorption (Matuchansky and Bernier, 1973). As in the rat, it is feasible that $\mathrm{PGE}_{1}$, in producing this magnitude of water flux, may inhibit glucose absorption indirectly by solvent drag.

The small inhibitory effect of prostaglandins on glucose absorption in the rat jejunum does not appear to be due to alteration in blood glucose concentration or to their vasoactive effects. It is not possible at this stage to determine whether their inhibitory effect is real or secondary to solvent drag. Other possible mechanisms such as increase in glucose metabolism or contraction of the villi also cannot be ruled out.

We are grateful to Miss Marianne Mann for preparing specimens for histological examination.

\section{References}

Al-Awqati, Q., and Greenough, W. B. (1972). Prostaglandins inhibit intestinal sodium transport. Nature [new Biol.], 238, 26-27.

Al-Awqati, Q., Cameron, J. L., Field, M., and Greenough, W. B. (1970a). Response of human ileal mucosa to choleragen and theophylline. J. clin. Invest., 49, 2 a.

Al-Awqati, Q., Field, M., Pierce, N. F., and Greenough, W. B. (1970b). Effect of prostaglandin $E_{1}$ on electrolyte transport in rabbit ileal mucosa. J. clin. Invest., 49, 2 a.

Casey, M. G., Felber, J.-P., and Vannotti, A. (1968), Biochemica study of the mechanism of intestinal absorption: effect of blood glucose levels on glucose absorption by the intestine in vitro. Digestion, 1, 233-237.

Casey, M. G., and Harrington, M. G. (1971). The effect of 3' 5' cyclic AMP on glucose absorption by the intestine. Irish J. Med., 140, 417.

Cochran, W. G., and Cox, G. M. (1957). In Experimental Designs, pp. 83-93. Chapman and Hall, London.

Coupar, I. M., and McColl, I. (1972). Inhibition of glucose absorption by prostaglandins $\mathrm{E}_{1}, \mathrm{E}_{2}$ and $\mathrm{F}_{2 a}$.J. Pharm. Pharmacol., 24, 254-255.

Dawson, W., Jessup, S. J., McDonald-Gibson, W., Ramwell, P. W., and Shaw, J. E. (1970). Prostaglandin uptake and metabolism by the perfused rat liver. Brit. J. Pharmacol., 39, 585-598.

Dinda, P. K., Beck, M., and Beck, I. T. (1972). Effect of changes in the osmolaeity of the luminal fluid on water and glucose transport across the hamster jejunum. Canad. Jl Physiol. Pharmacol., 50, 83-86.

Field, M., and McColl, I. (1968). Contrasting effects of epinephrine and cyclic AMP on ion transport across intestine. Fed. Proc., 27, 603.

Field, M., Plotkin, G.R., and Silen, W. (1968). Effects of vasopressin, theophylline and cyclic adenosine monophosphate on shortcircuit current across rabbit ileal mucosa. Nature (Lond.), 217, 469-471.

Field, M., Fromm, D., and Silen, W. (1969). Effect of theophylline on intestinal Na transport. Fed. Proc., 28, 651.

Ferreira, S. H., and Vane, J. R. (1967). Prostaglandins: their disappearance from and release into the circulation. Nature
(Lond.), 216, 868-873

Greenough, W. B., Pierce, N. F., Al-Awqati, Q., and Carpenter, C. C. J. (1969). Stimulation of gut electrolyte secretion by prostaglandins, theophylline and cholera exotoxin. J. clin. Invest., 48, 32-33a.

Hertting, G. (1964). The fate of ${ }^{3} \mathrm{H}$-iso-proterenol in the rat. Biochem. Pharmacol., 13, 1119-1128.

Iber, F. L., McGonagle, T., Serebro, H. A., Luebbers, E., Bayless, T. M., and Hendrix, T. R. (1969). Unidirectional sodium flux in small intestine in experimental canine cholera. Amer. J. med. Sci., 258, 340-350.

Innes, I. R., and Nickerson, M. (1970). In The Pharmacological Basis of Therapeutics, edited by L. S. Goodman, and A. Gilman, pp. 499-500. MacMillan, London.

Kimberg, D. V., Field, M., Johnson, J., Henderson, A., and Gershon, E. (1971). Stimulation of intestinal mucosal adenyl cyclase by cholera enterotoxin and prostaglandins. J. clin. Invest., 50, 12181230.

Lichtenstein, B., and Winne, D. (1973). The influence of blood flow on the absorption of 3-O-methylglucose from the jejunum of the rat. Naunyn-Schmiedebergs Arch. Pharmacol., 279, 153-172.

McColl, I., Field, M., and Silen, W. (1968). Stimulation of electrolyte absorption from the ileum by epinephrine and norepinephrine. Gastroenterology, 54, 1255.

Matuchansky, C., and Bernier, J.J. (1971). Effects of prostaglandin $E_{1}$ on net and unidirectional movements of water and electrolytes across the jejunal mucosa in man. Gut, 12, 854-855.

Matuchansky, C., and Bernier, J.-J. (1973). Effect of prostaglandin E on glucose water, and electrolyte absorption in the human jejunum. Gastroenterology, 64, 1111-1118.

Nakano, J. (1973). General pharmacology of prostaglandins: In The Prostaglandins, edited by M. F. Cuthbert, pp. 23-124. Heinemann, London.

Nissim, J. A. (1965). The study and assay of substances affecting intestinal absorption in the mouse. Brit. J. Pharmacol. Chemother., 24, 205-213.

Parkinson, T. M., and Schneider, J. C. (1969). Absorption and metabolism of prostaglandin $\mathrm{E}_{1}$ by perfused jejunum in vitro. Biochim. biophys. Acta (Amst.), 176, 78-85.

Pierce, N. F., Carpenter, C. C. J., Elliot, H. L., and Greenough, W. B. (1971). Effects of prostaglandins, theophylline and cholera exotoxin upon transmucosal water and electrolyte movement in the canine jejunum. Gastroenterology, 60, 22-32.

Piper, P. J., Vane, J. R., and Wyllie, J. H. (1970). Inactivation of prostaglandins by the lungs. Nature (Lond.), 225, 600-604.

Radmanovic, B. (1968). Prostaglandins in perfusate of the rat small intestine after vagal stimulation. Jugoslav. Physiol. Pharmacol. Acta, 4, 123-124.

Serebro, H. A., Bayless, T. M., Hendrix, T. R., Iber, F. L., and McGonagle, T. (1968). Absorption of d-glucose by the rabbit jejunum during cholera toxin-induced diarrhoea. Nature (Lond.), 217, 1272-1273.

Sharp, G. W. G., and Hynie, S. (1971). Stimulation of intestinal adenyl cyclase by cholera toxin. Nature (Lond.), 229, 266-269.

Snedecor, G. L., and Cochran, W. G. (1967). In Statistical Methods, pp. 272-273. The Iowa State University Press, Ames, Iowa.

Viguera, M. G., and Sunahara, F. A. (1969). Microcirculatory effects of prostaglandins. Canad. J. Physiol. Pharmacol., 47, 627-634.

Waller, S. L. (1973). Prostaglandins and the gastrointestinal tract. Gut, 14, 402-417.

Weeks, J. R., and Wingerson, F. (1964). Cardiovascular action of prostaglandin $E_{1}$ evaluated using unanesthetized relatively unrestrained rats. Fed. Proc., 23, 327.

Weiner, R., and Kaley, G. (1969). Influence of prostaglandin $E_{1}$ on the terminal vascular bed. Amer. J. Physiol., 217, 563-566.

Windmueller, H. G., Spaeth, A. E., and Ganote, C. E. (1970). Vascular perfusion of isolated rat gut: norepinephrine and glucocorticoid requirement. Amer. J. Physiol., 218, 197-204. 